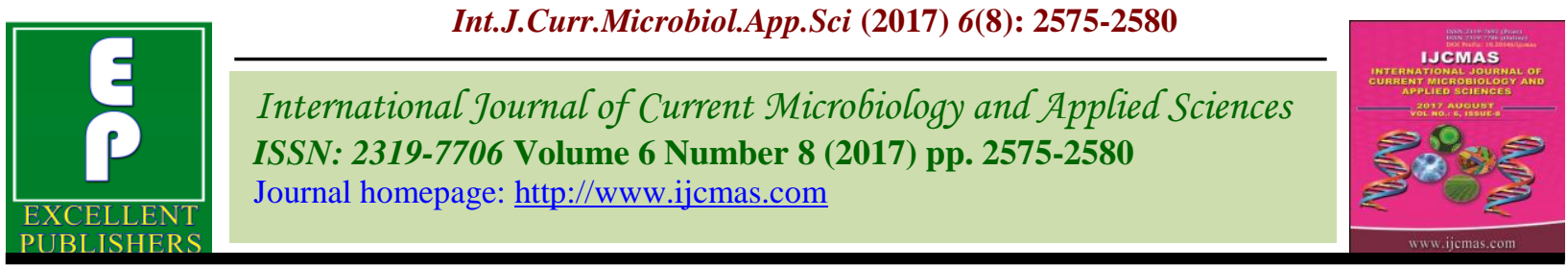

Original Research Article

https://doi.org/10.20546/ijcmas.2017.608.305

\title{
An Evaluation of P Adsorption Indices of Some Representative Soils of Chhattisgarh, India
}

\author{
Lalit Kumar Yadav and G.K. Jatav* \\ Soil Science and Agricultural Chemistry, Indira Gandhi Krishi Vishwavidhyalaya, \\ Raipur-492012, Chhattisgarh, India \\ *Corresponding author
}

\section{A B S T R A C T}

A laboratory study was undertaken to investigate the $\mathrm{P}$ adsorption behavior of three representative soils of Chhattisgarh belonging to the order Inceptisol, Alfisol and Vertisol. Experiment was conducted to examine the "An evaluation of $\mathrm{P}$ adsorption indices of some representative soils of Chhattisgarh" phosphorus adsorption were determined from surface $(0-15 \mathrm{~cm})$ bulk soil samples each from different sites belonging to three order- Inceptisol, Alfisol and Vertisol were collected from the experimental farm so as to have large

\section{Keywords}

Evaluation of $\mathrm{P}$ adsorption, Soils of Chhattisgarh.

Article Info

Accepted:

21 June 2017

Available Online:

10 August 2017 variation in their properties and investigated by applying Langmuir and Freundlich adsorption equation to the $\mathrm{P}$ adsorption data. The $\mathrm{P}$ adsorption at the solid phase was strongly related to its concentration in the solution phase and Vertisol with maximum clay content recorded highest $\mathrm{P}$ adsorption at a given equilibrium $\mathrm{P}$ concentration indicating that $\mathrm{P}$ ions are most tightly held by Vertisol. The identical and high values of $\mathrm{R}^{2}$ both for Langmuir and Freundlich Adsorption Isotherms indicated that the $\mathrm{P}$ adsorption data conformed to both isotherms indicating their goodness of fit. The P adsorption maxima ' $b$ ' was highest for Vertisol followed by Alfisol and Incptisol. The value of Langmuir ' $\mathrm{K}$ ' showed an increasing trend in the same order indicating a high affinity of Vertisol for $\mathrm{P}$, which had resulted in higher value of ' $b$ '. The value of Freundlich ' $n$ ' showed a slight increasing trend in the order Vertisol > Alfisol > Inceptisol, whereas, its ' $\mathrm{K}$ ' value showed a decreasing trend in the same order. $\mathrm{P}$ adsorption maxima was significantly and positively correlated with $\mathrm{pH}\left(\mathrm{r}=0.85^{* *}\right)$, clay $(\mathrm{r}=0.96 * *)$ and silt + clay $(\mathrm{r}=0.94 * *)$, however, the binding energy showed a significant and positive correlation ship with organic carbon $\left(\mathrm{r}=0.68^{*}\right)$ only. In case of Freundlich Isotherm, however, that there was no significant relationship between Freundlich Adsorption parameters and properties except between the empirical constant ' $\mathrm{K}$ ' and soil $\mathrm{pH}(\mathrm{r}=0.68 *)$.

\section{Introduction}

The term "Available Phosphorus" determined by soil test is often used to indicate a soil $\mathrm{P}$ fraction that can be utilized by plants.

However, this term is very vague as it only predict whether or not fertilizer $\mathrm{P}$ is required and usually refers back to soil extraction methods, which often vary from observation of crop response.
The properties of added $\mathrm{P}$ sorption under a given set of conditions should be considered along with the final concentration in the solution or the resulting degree of saturation. The relationship between labile $\mathrm{P}$ sorbed to the soil surface (quantity-Q) and solution $\mathrm{P}$ (intensity) can be described by a quantity intensity relationship or Q/I plot, which shows $\mathrm{P}$ sorption or desorption as a function of $\mathrm{P}$ in 
the equilibrium solution. The shape of the curve reflects the $\mathrm{P}$ sorption capacity and the slope of the curve reflects the buffering capacity for freshly added P (Bache \& Williams, 1971). The shape and placement of the $\mathrm{Q} / \mathrm{I}$ plot depends $\mathrm{b}$ is doth on soil properties and $\mathrm{P}$ fertilization history. Previous fertilization with $P$ can reduce the ability of the soil to sorb $\mathrm{P}$ by blocking sorption sites and thus change the placement and decrease the slope of the Q/I plot (Barrow, 1974; Hartikainen1991).

The quantity factor has been defined as the total quantity of labile $\mathrm{P}$ which enters the soil solutions during isoionic exchange within an appropriate time (Larsen 1967). The quantity factor is the replenishment of soil solution when its intensity depleted by the removal of the $\mathrm{P}$ crops.

The buffering capacities as defined by quantity- intensity factor suggest the change in the quantity factor per unit change in the intensity of $\mathrm{P}$ in soil solution. This concept of quantity- intensity relationship has proved a useful guide in improving the understanding of $\mathrm{P}$ supply to the roots.

Interaction of quantity result, and buffuering capacity, expressed as dimension less supply parameter (SP), determines the ability of the soils to supply $\mathrm{P}$ to growing plant roots.

Equations such as the Langmuir, Freundlich and Tempkin models have been used to describe the relationship between the amount of $\mathrm{P}$ adsorbed to the $\mathrm{P}$ in solution at equilibrium (Berkheiser et al., 1980; Nair et al., 1984).The sorption maximum derived from the Langmuir equation is useful for estimating $\mathrm{P}$ sorption capacity and for comparing different soils. An advantage of using Langmuir equation is that it defines a limit to adsorption on a given array of sites. Adsorption of $\mathrm{P}$ by soils from the dilute solution has shown closer agreement with the Langmuir Isotherms than several other Isotherms. Therefore, this equation has been used by several investigators to estimate the adsorption capacity of soils as well as adsorption behavior (Thompson et al., 1960; Das et al., 1983; Vig and Dev, 1984; Ksishna Kumari et al., 1985.)

The soils of Vertisol, Alfisol and Inceptisol orders in Chhattisgarh region are deficient in phosphorus which results it large response to $P$ fertilizers. It has been observed that at similar low Olsen P levels, Inceptisols are able to produce better crop yields than Vertisols.

Significant residual $\mathrm{P}$ buildup in Vertisols has also been observed due to fertilization as a result of high $\mathrm{P}$ fixation capacity (Patil et al., 2000). The above observations suggest that the strength with which $\mathrm{P}$ is retained in these soils and their $\mathrm{P}$ fixation capacities determine the extraction of $\mathrm{P}$ by plants from these soils.

Thus adsorption studies may prove helpful to understand this aspect of $\mathrm{P}$ nutrition of crops. Therefore a study entitled.

\section{Materials and Methods}

A Laboratory study was undertaking to investigate the $\mathrm{P}$ adsorption behavior of three representative soil of Chhattisgarh belonging to the order Inceptisol, Alfisol and Vertisol.

Four Soil surface $(0-15 \mathrm{~cm})$ bulk soil samples each from different sites belonging to three soil orders - Inceptisol, Alfisol and Vertisol were collected from the experimental farm so as to have large variation in their properties. The samples were air dried, ground and passed through $2 \mathrm{~mm}$ sieve and used for adsorption studies in accordance with the method described by Fox and Kamprath (1970). 


\section{Phosphorus adsorption study}

Data for plotting $\mathrm{P}$ adsorption isotherms were obtained by equilibrating $5 \mathrm{~g}$ soil in triplicate for 24 hours at $25^{0} \mathrm{C}$ in $50 \mathrm{ml} \mathrm{C}_{\mathrm{a}} \mathrm{Cl}_{2}$ solution containing varying amounts of $\mathrm{P}(0,30,60$, $90,120,150,180,210,240,270$ and 300 ppm) as $\mathrm{KH}_{2} \mathrm{PO}_{4}$. Equilibration was carried out in $50 \mathrm{ml}$ centrifuge tubes by shaking for 24 hours. After shaking, the samples were centrifuged at $2500 \mathrm{rpm}$ for 10 minutes and then the concentration of $\mathrm{P}$ in the clear solution was determined by ascorbic acid method using Double Beam Spectrophotometer.

The $\mathrm{P}$ which disappeared from the solution was considered to be adsorbed and calculated as:

Amount of $\mathrm{P}$ adsorbed in $\mu \mathrm{g} \mathrm{g}^{-1}(\mathrm{x} / \mathrm{m})=$ Initial conc. of the equilibrium solution -final concentration of the equilibrium solution in ppm (C).

The Buffering capacity is defined as "change in adsorption $\mathrm{P}$ per unit change in the solution $\mathrm{P}$ and is expressed as:

$\mathrm{BC}=\frac{\Delta \mathrm{Q}}{\Delta \mathrm{I}}$

Where,

$\mathrm{Q}=\mathrm{Quantity}(\mathrm{P}$ in solid phase)

$\mathrm{I}=$ Intensity ( $\mathrm{P}$ in solution phase)

$\Delta \mathrm{Q}=$ Change in $\mathrm{Q}$

$\Delta \mathrm{I}=$ Change in $\mathrm{I}$

The buffering Capacity was computed as suggested by Bowman and Olsen (1985a, 1985b). A graph (scatter diagram) was plotted by taking $\mathrm{x} / \mathrm{m}$ (quantity) on $\mathrm{Y}$-axis and $\mathrm{C}$ (Intensity) on $\mathrm{X}$-axis and a straight line equation was fitted to the data to obtain the values of slope (BC).

\section{Results and Discussion}

This chapter deals with finding of the $\mathrm{P}$ adsorption study conducted to investigate the $\mathrm{P}$ adsorption behavior of same representative soils of Chhattisgarh. The P adsorption study was conducted on three soils namely Inceptisol, Alfisol and Vertisol.

The amount of $\mathrm{P}$ adsorb $(\mathrm{x} / \mathrm{m})$, amount of $\mathrm{P}$ remaining in the equilibrium solution $(\mathrm{C})$ and correlation coefficient, ( $r$ ) between $\mathrm{C}$ and $(\mathrm{x} / \mathrm{m})$ for all the three soils are given in table 1-3. The correlation coefficient ' $r$ ' between $C$ and $(\mathrm{x} / \mathrm{m})$ was found to be highly significant (Table 1-3) for all the soils indicating that $\mathrm{P}$ adsorption at the solid phase was strongly related to its concentration in the solution phase.

The adsorption of $\mathrm{P}$ was low at lower equilibrium $\mathrm{P}$ concentration and increased with an increase in equilibrium $P$ concentration as also reported by Toor et al., (1997).

The soil having divergent texture showed widely different behavior asis evident from the shape of the C- $(\mathrm{x} / \mathrm{m})$ curve which indicates that vertisol adsorbed maximum $\mathrm{P}$ and Inceptisol minimum at a given equilibrium $\mathrm{P}$ concentration while Alfisol remained intermediate. This variation can be attributed to the wide variation in the clay content of these soils which governs the adsorption site and total surface area (Sanyal and Dutta, 1951).

Thus vertisol with maximum clay content showed highest adsorption and Inceptisol with minimum clay content showed lowest $\mathrm{P}$ adsorption. This indicates that $\mathrm{P}$ ions are most tightly held by Vertisol as has also been reported earlier by Patil et al., (2000). Bahl et al., (1986) also found that the adsorption capacity was higher in soils 
Table.1 Phosphorus adsorption characteristics of inceptisol

\begin{tabular}{|c|c|c|c|c|c|c|c|c|}
\hline $\begin{array}{c}\text { Initial cone. } \\
(\mathbf{p p m})\end{array}$ & \multicolumn{2}{|c|}{$\mathbf{A}$} & \multicolumn{2}{c|}{$\mathbf{B}$} & \multicolumn{2}{c|}{$\mathbf{C}$} & \multicolumn{2}{c|}{$\mathbf{D}$} \\
\cline { 2 - 9 } & $\mathbf{C}$ & $\mathbf{x} / \mathbf{m}$ & $\mathbf{C}$ & $\mathbf{x} / \mathbf{m}$ & $\mathbf{C}$ & $\mathbf{x} / \mathbf{m}$ & $\mathbf{C}$ & $\mathbf{x} / \mathbf{m}$ \\
\hline 30 & 15.6 & 14.4 & 9.5 & 20.5 & 4.9 & 25.1 & 11.3 & 18.7 \\
\hline 60 & 33.1 & 26.9 & 24.2 & 35.8 & 20.6 & 39.4 & 28.2 & 31.8 \\
\hline 90 & 52.9 & 37.1 & 44.7 & 45.3 & 39.8 & 50.2 & 48.3 & 41.7 \\
\hline 120 & 76.0 & 44.0 & 67.5 & 52.5 & 63.2 & 56.8 & 68.2 & 51.8 \\
\hline 150 & 101.0 & 49.0 & 93.9 & 56.1 & 84.0 & 66.0 & 91.1 & 58.9 \\
\hline 180 & 122.8 & 57.2 & 118.7 & 61.3 & 114.8 & 65.3 & 115.2 & 64.8 \\
\hline 210 & 149.7 & 60.3 & 147.6 & 62.4 & 140.7 & 69.3 & 139.8 & 70.2 \\
\hline 240 & 172.3 & 67.7 & 175.2 & 64.8 & 172.2 & 67.8 & 168.6 & 71.4 \\
\hline 270 & 200.2 & 69.8 & 201.0 & 69.0 & 202.3 & 67.7 & 190.9 & 79.1 \\
\hline 300 & 223.4 & 76.6 & 231.4 & 68.6 & 231.6 & 68.4 & 220.7 & 79.3 \\
\hline \multicolumn{2}{|c|}{$\mathrm{r}=0.98^{* *}$} & \multicolumn{2}{|c|}{$\mathrm{r}=0.90^{* *}$} & \multicolumn{2}{c}{$\mathrm{r}=0.82^{* *}$} & & $\mathrm{r}=0.95^{* *}$ \\
\hline
\end{tabular}

$\mathrm{C}=\mathrm{P}$ remaining in solution, $\mu \mathrm{g} \mathrm{ml}^{-1} \mathrm{x} / \mathrm{m}=\mathrm{P}$ adsorbed $\mu \mathrm{g} \mathrm{g}-1$ of soil

' $\mathrm{r}$ ' is the correlation coefficient between $(\mathrm{x} / \mathrm{m})$ and equilibrium $\mathrm{P}$ concentration $\mathrm{C}$

Table.2 Phosphorus adsorption characteristics of Alfisol

\begin{tabular}{|c|c|c|c|c|c|c|c|c|}
\hline \multirow{2}{*}{$\begin{array}{c}\text { Initial cone. } \\
(\mathbf{p p m})\end{array}$} & \multicolumn{2}{|c|}{$\mathbf{A}$} & \multicolumn{2}{c|}{$\mathbf{B}$} & \multicolumn{2}{c|}{$\mathbf{C}$} & \multicolumn{2}{c|}{$\mathbf{D}$} \\
\cline { 2 - 9 } & $\mathbf{C}$ & $\mathbf{x} / \mathbf{m}$ & $\mathbf{C}$ & $\mathbf{x} / \mathbf{m}$ & $\mathbf{C}$ & $\mathbf{x} / \mathbf{m}$ & $\mathbf{C}$ & $\mathbf{x} / \mathbf{m}$ \\
\hline 30 & 3.8 & 26.2 & 3.3 & 26.7 & 3.6 & 26.5 & 3.9 & 26.1 \\
\hline 60 & 12.0 & 48.0 & 9.8 & 50.2 & 11.3 & 48.7 & 13.3 & 46.7 \\
\hline 90 & 23.7 & 66.3 & 15.3 & 74.7 & 19.3 & 70.7 & 20.3 & 69.7 \\
\hline 120 & 35.7 & 84.3 & 25.0 & 95.0 & 31.4 & 88.6 & 32.7 & 87.3 \\
\hline 150 & 49.7 & 100.3 & 44.6 & 105.4 & 41.0 & 109.0 & 53.4 & 96.6 \\
\hline 180 & 66.7 & 113.3 & 59.3 & 120.7 & 55.6 & 124.4 & 73.0 & 107.0 \\
\hline 210 & 78.0 & 132.0 & 85.4 & 124.6 & 71.4 & 138.6 & 87.5 & 122.5 \\
\hline 240 & 103.2 & 136.8 & 101.0 & 139.0 & 91.7 & 148.2 & 106.6 & 133.4 \\
\hline 270 & 116.0 & 154.0 & 120.4 & 149.6 & 115.8 & 154.2 & 132.0 & 138.0 \\
\hline 300 & 132.4 & 167.6 & 143.0 & 157.0 & 143.3 & 156.7 & 157.3 & 142.7 \\
\hline \multicolumn{7}{|c|}{$\mathrm{R}=0.98^{* *}$} & \multicolumn{7}{|c|}{$\mathrm{R}=0.93^{* *}$} & \multicolumn{2}{c}{$\mathrm{R}=0.91 * *$} & $\mathrm{R}=094 * *$ \\
\hline
\end{tabular}

Table.3 Phosphorus adsorption characteristics of vertisol

\begin{tabular}{|c|c|c|c|c|c|c|c|c|}
\hline $\begin{array}{c}\text { Initial cone. } \\
(\mathbf{p p m})\end{array}$ & \multicolumn{2}{|c|}{$\mathbf{A}$} & \multicolumn{2}{c|}{$\mathbf{B}$} & \multicolumn{2}{c|}{$\mathbf{C}$} & \multicolumn{2}{c|}{$\mathbf{D}$} \\
\cline { 2 - 9 } & $\mathbf{C}$ & $\mathbf{x} / \mathbf{m}$ & $\mathbf{C}$ & $\mathbf{x} / \mathbf{m}$ & $\mathbf{C}$ & $\mathbf{x} / \mathbf{m}$ & $\mathbf{C}$ & $\mathbf{x} / \mathbf{m}$ \\
\hline 30 & 2.3 & 27.7 & 1.5 & 28.5 & 2.6 & 27.4 & 2.3 & 27.7 \\
\hline 60 & 4.9 & 55.1 & 2.9 & 57.1 & 4.7 & 55.3 & 8.3 & 51.7 \\
\hline 90 & 7.2 & 82.8 & 6.4 & 83.6 & 8.4 & 81.6 & 13.4 & 76.6 \\
\hline 120 & 11.7 & 108.3 & 13.4 & 106.6 & 13.0 & 107.0 & 25.7 & 94.3 \\
\hline 150 & 21.0 & 129.0 & 21.4 & 128.6 & 20.8 & 129.2 & 33.6 & 116.4 \\
\hline 180 & 27.2 & 152.8 & 27.8 & 152.2 & 27.4 & 152.6 & 47.8 & 132.2 \\
\hline 210 & 41.8 & 168.2 & 42.6 & 167.4 & 36.0 & 174.0 & 59.9 & 150.1 \\
\hline 240 & 51.9 & 188.1 & 65.3 & 174.7 & 48.6 & 191.4 & 77.1 & 162.9 \\
\hline 270 & 63.2 & 206.8 & 85.4 & 184.6 & 57.6 & 212.4 & 89.5 & 180.5 \\
\hline 300 & 74.3 & 225.7 & 102.5 & 197.5 & 71.9 & 228.1 & 110.8 & 189.2 \\
\hline \multicolumn{7}{|c|}{$\mathrm{R}=0.95^{* *}$} & \multicolumn{7}{|c|}{$\mathrm{R}=0.88^{* *}$} & $\mathrm{R}=0.96^{* *}$ & & $\mathrm{R}=0.96^{* *}$ \\
\hline
\end{tabular}


The P buffering capacity was computed from the slope of the graph plotted between $(\mathrm{x} / \mathrm{m})$ and equilibrium $\mathrm{P}$ concentration for three soils types averaged over four samples. The value of buffering capacity obtained for Vertisol, Alfisol and Inceptisol were 1.90, 0.86 and 0.22 respectively. The buffering capacity values thus obtained indicated that to maintain a given intensity of $\mathrm{P}$ in solution maximum quantity of $\mathrm{P}$ in the solid phase would be required for Vertisol followed by Alfisol and Inceptisol. Lakshmi et al., (1987) reported that buffering capacity tended to increase with clay content. Sahrawat and Waren (1989) reported that Vertisol and higher capacity and buffer power for $\mathrm{P}$ adsorption than Alfisol, implying a lower response of the former to fertilizer $\mathrm{P}$.

The $\mathrm{P}$ sorption at $2.2 \mathrm{ppm}$ solution concentration which has been used as a standard for comparing $\mathrm{P}$ requirement of soils (Loganathan et al., 1987) was also computed for the soils under investigation and was found to be $61.40,49.27$ and 30.19 for Vertisol, Alfisol and Inceptisol respectively. These values agree with the trend of $\mathrm{P}$ adsorption behavior as evident from Langmuir plots.

Beckwith (1965) reported that $0.2 \mathrm{ppm}$ concentration of $\mathrm{P}$ if maintain continuously in soil solution will provide adequate $\mathrm{P}$ to plants. Fox and Kamprath (1970) also suggested that the amount of $\mathrm{P}$ adsorbed to give a solution concentration of $0.2 \mathrm{ppm}$ can be considered agronomically relevant estimate of $P$ adsorption. Ozame and Shaw, (1968) however, stated that $0.3 \mathrm{ppm}$ can be taken to predict the $\mathrm{P}$ availability of crops. The variation in the value of $P$ sorbed at $0.2 \mathrm{ppm}$ solution $\mathrm{P}$ concentration by these soils imply that for maintaining soil solution $\mathrm{P}$ to support normal plant growth Vertisol will require more solid phase $\mathrm{P}$ followed by Alfisol and Inceptisol.

\section{References}

Bahl, G.S., and sinha, M.K. 1971.Adsorption and surface reactivity of phosphates in some soils of Punjab. Proceeding International Symposium on Use of Isotopes and Radioisotope in Agriculture and Animal Husbandry Research. New Delhi. 348 - 355.

Bhal, G.S., Singh, N.T. and Vig, A.C. 1986. Phosphate uptake by maize and wheat in relation to $\mathrm{P}$ adsorption characteristics of soils. J. Indian Soc. Soil Sci. 34:791-798.

Biswas, P.P., Joshi, O.P. and Rajput, M.S. 1989. Characterization of mango orchards in relation to $\mathrm{P}$ supplying capacity of soils. J. Indian Soc. Soil Sci.34: 193-196.

Bowman, R.A. and Olsen, S.R. 1985a.Assessment of Phosphate buffering capacity: 1. Laboratory methods Soil Science.140 (4): 287-291.

Bowman, R.A. and Olsen, S.R. 1985b.Assessment of phosphate buffering capacity: 2. Greenhouse methods. Soil Science. 140 (5): 387-392.

Das, S.K., Rishi, A. K. and Goswami, N.N. 1983. Quantity factors of soil phosphate and utilization of fertilizer phosphate by barley. J. Indian Soc. Soil Sci. 31: 4346.

Doddamani, V.S. and Rao, T.S. 1989. Phosphate adsorption characteristics of some soil types of Karnataka, Journal of Agricultural Science. 231:18-25.

Fox, R.L. and Kamprath, E.J. 1970. Phosphate sorption isotherms for evaluating the phosphate requirement of soils. Soil Science of America Proceeding. 34: 902-906.

Hartar, R.D. 1969. Phosphate adsorption sites in soils. Soil Sci. Soc. Am. Proc. 33: 630-632.

Hartono, A., Funakawa, S. and Kosaki, T. 2005. Phosphorus sorption desorption 
characteristics of selected acid upland soils of Indonesia. Soil Science and Plant Nutrition. 516: 787:799.

Krishna Kumari, G., Adinarayana, V. Subba Rao, A. and Pillai, R.N. 1985. Phosphate adsorption in some representative soils of Andhra Pradesh. J. Indian Soc. Soil Sci. 33: 666-668.

Mondal, A.K., Jalali, V.K., Pareek, N. and Wali, P. 2004. Phosphorus adsorption characteristics of subtropical soils of Jammu region. J. Indian Soc. Soil Sci. 521:188-191.

Munna Ram, R.N., Prasad and Patiram 1987. Studies on Phosphate adsorption and Phosphate fixation in Alfisols occurring in different altitude of Meghalaya. J. Indian Soc. Soil Soc., Vol. 35.207-216.

Patil, S.K., Tiwari, P.K., Das, R.O. and Mishra, V.N. 2000.Identification of $\mathrm{P}$ reaction products and adsorption behavior in the soils of Chhattisgarh, M.P.J. Soils and Crops. 101:25-29.

Patiram, R.N., Rai and R.N. Prasad. 1990. Phosphate adsorption by acid soils from different altitude. J. Indian Soc. Soil Sci. Vol 38.602-608.

Ram, M., Prasad, R.N. and Ram, P. 1987.Studied of phosphate adsorption and phosphate fixation in Alfisols and Entisols occurring in different altitude of Meghalaya. J. Indian Soc. Soil Sci. 35:207- 216.

Sahrawat, K.L. and Warren, G.P. 1989. Sorption of labeled phosphate by a Vertisol and an Alfisol of the semiarid zone of Indian. Fertilizer Research. 20: 17-25.

Tomar, N.K. 2000. Dynamics of Phosphorus in Soils. J. Indian Soc. Soil Sci. 48, (4).640-673.

Toor, G.S., Bahl, G.S. and Vig, A.C. 1997. Pattern of $\mathrm{P}$ availability in different soils as assessed by different adsorption equations. J. Indian Soc. Soil Sci. 45-4, 119-723.

Vig, A.C. and Dev, G. 1974.Quantity intensity relationships of phosphorus on soils from North Western India. Plant Production Proceeding Symposium. 250-259.

Woodruff, J.R. and Kamprath, E.J. 1965.Phosphorus adsorption maximum as measured by the Langmuir isotherm and its relationship to phosphorus availability. Soil. Sci. Soc. Am. Proc. 29: $148-150$.

\section{How to cite this article:}

Lalit Kumar Yadav and Jatav, G.K. 2017. An Evaluation of P Adsorption Indices of Some Representative Soils of Chhattisgarh, India. Int.J.Curr.Microbiol.App.Sci. 6(8): 2575-2580. doi: https://doi.org/10.20546/ijcmas.2017.608.305 